\title{
DETERMINAN NILAI PERUSAHAAN \\ (STUDI PADA BANK UMUM YANG TERDAFTAR DI BURSA EFEK INDONESIA PERIODE 2015-2019)
}

\author{
${ }^{1}$ Dwi Epty Hidayaty \\ ${ }^{2}$ Wike Pertiwi \\ Program Studi Manajemen, Fakultas Ekonomi dan Bisnis, \\ Universitas Buana Perjuangan Karawang \\ dwi.epty@ubpkarawang.ac.id ${ }^{1}$ \\ wike.pertiwi@ubpkarawang.ac.i $d^{2}$
}

\begin{abstract}
ABSTRAK
Penelitian ini bertujuan untuk mengidentifikasi dinamika profitabilitas, likuiditas, dan struktur modal pada bank umum yang terdaftar di BEI periode 2015-2019, mengidentifikasi pengaruhnya dan memformulasikan implikasi manajerial dan merekomendasi kesimpulan bahwa ada pengaruh dari Return on Equity (ROE), Debt To Equity Ratio (DER), dan Loan To Deposit Ratio (LDR) terhadap Price To Book Value (PBV). Penelitian ini adalah penelitian kausal dengan pendekatan kuantitaif dimana variabel independennya adalah profitabilitas, struktur modal, dan likuiditas, sedangkan untuk variabel dependennya adalah perusahaan. Analisis data yang digunakan adalah analisis statistik inferensia. Penelitian ini menggunakan analisis regresi data panel yang diolah dengan menggunakan SPSS versi 23. Hasil penelitian didapatkan pada uji asumsi diketahui bahwa error term sudah memenuhi asumsi normal dan tidak terdapat multikolinearitas dan heteroskedastisitas. Pada uji hipotesis koefisien determinasi, diketahui bahwa sample dapat secara baik mempresentasikan total populasi, dan pada uji regresi simultan (Uji F) didapatkan bahwa variabel independen (ROE, DER, LDR) secara simultan berpengaruh signifikan pada variabel dependen (PBV). Dari hasil penelitian menyatakan bahwa Return on Equity (ROE) berpengaruh positif dan signifikan terhadap nilai perusahaan. Sedangkan untuk variabel lainnya seperti Debt To Equity Ratio (DER) berpengaruh negatif dan tidak signifikan terhadap nilai perusahaan (PBV) dan Loan To Deposit Ratio (LDR) berpengaruh dan signifikan terhadap nilai perusahaan $(\mathrm{PBV})$.
\end{abstract}

Kata kunci: Nilai Perusahaan, Profitabilitas, Struktur Modal, Likuiditas

\begin{abstract}
This study aims to identify the dynamics of profitability, liquidity, and capital structure in commercial banks listed on the IDX for the 2015-2019 period, identify their effects and formulate managerial implications and recommend the conclusion that there is an effect of Return on Equity (ROE), Debt To Equity Ratio (DER), and Loan To Deposit Ratio (LDR) against Price To Book Value (PBV). This research is a causal research with a quantitative approach where the independent variables are profitability, capital structure and liquidity, while the dependent variable is the company. The data analysis used was statistical inferential analysis. This study uses panel data regression analysis which is processed using SPSS version 23. The results obtained in the assumption test note that the error term has met the normal assumptions and there is no multicollinearity and heteroscedasticity. In the coefficient of determination hypothesis test, it is known that the sample can represent the total population well, and in the simultaneous regression test ( $\mathrm{F}$ test) it is found that the independent variables (ROE, DER, LDR) simultaneously have a significant effect on the dependent variable (PBV). From the results of the study states that Return on Equity (ROE) has a positive and significant effect on firm value. Meanwhile, other variables such as Debt To Equity Ratio (DER) have a negative and insignificant
\end{abstract}


effect on firm value (PBV) and Loan To Deposit Ratio (LDR) has a significant and significant effect on firm value $(\mathrm{PBV})$.

Keywords: Firm Value, Profitability, Capital Structure, Liquidity

\section{PENDAHULUAN}

Kegiatan perekonomian Indonesia tidak terlepas dari peran perbankan, karena hampir seluruh proses perputaran uang terjadi melalui perbankan. Sektor perbankan memiliki peran dalam memacu peningkatan kesejahteraan rakyat, selain peranannya dalam pelaksana lalu lintas pembayaran yang juga sebagai sarana intermediasi, sektor perbankan juga sebagai alat transmisi moneter. Peran inilah yang menyebabkan setiap perubahan dalam sektor perbankan akan menimbulkan dampak terhadap sektor lainnya.

Menurut Salvatore (dalam Hermuningsih 2013:128) menyatakan bahwa tujuan utama perusahaan yang telah go public adalah meningkatkan kemakmuran pemilik atau para pemegang saham melalui peningkatan nilai perusahaan. Nilai perusahaan berperan sangat penting karena dengan nilai perusahaan yang tinggi akan diikuti oleh tingginya kemakmuran pemegang saham. Menurut Kusumajaya (dalam Putu Yunita et al. 2014:1) menjelaskan bahwa semakin tinggi nilai perusahaan menggambarkan semakin sejahtera pemilik perusahaan.

Nilai perusahaan adalah persepsi investor terhadap perusahaan, yang sering dikaitkan dengan harga saham, karena harga saham saat ini mencerminkan penilaian investor terhadap perusahaan di masa yang akan datang. Jika perusahaan mengambil keputusan yang buruk maka harga saham akan turun. Oleh karena itu, tujuan manajemen adalah mengambil keputusan yang bisa menaikan harga saham, karena ini akan menghasilkan kekayaan bagi pemegang saham, sehingga akan meningkatkan nilai perusahaan (Brigham \& Houston, 2006:8).

Nilai perusahaan dapat diukur dengan price to book value (PBV), yaitu perbandingan antara harga saham dengan nilai buku per saham (Brigham \& Gapenski dalam Hermuningsih, 2013:131). Dalam hal ini, PBV dapat diartikan sebagai hasil perbandingan antara harga pasar saham dengan nilai buku saham. PBV yang tinggi akan meningkatkan kepercayaan pasar terhadap prospek perusahaan dan mengindikasi kemakmuran pemegang saham yang tinggi (Soliha \& Taswan dalam Hermuningsih, 2013:131). Faktor yang dapat mempengaruhi nilai perusahaan adalah profitabilitas. Menurut (Mahendra et al. dalam Wulandari, 2014:459) profitabilitas merupakan tingkat keuntungan bersih yang mampu diraih perusahaan pada saat menjalankan operasinya. Pengukuran profitabilitas dengan menggunakan return on equity 
(ROE), yaitu rasio antara laba bersih setelah pajak terhadap penyertaan modal sendiri pada perusahaan (Putu Yunita, 2014:3).

Faktor selanjutnya yang dapat mempengaruhi nilai perusahaan adalah struktur modal. Menurut (Sitanggang, 2016:29) Debt to equity (DER), yaitu rasio antara total hutang dengan total ekuitas dalam perusahaan yang memberi gambaran perbandingan antara total hutang dengan modal sendiri (equity) perusahaan. Semakin tinggi rasio DER, semakin besar persentase modal asing yang digunakan dalam operasional perusahaan, atau semakin besar DER menandakan struktur permodalan usaha lebih banyak memanfaatkan hutang-hutang relatif terhadap ekuitas (Rompas, 2013:256).

Faktor lainnya yang dapat mempengaruhi nilai perusahaan adalah likuiditas. Menurut (Tampubolon, 2013:43) rasio likuiditas menunjukan tingkat kemudahan relatif suatu aktiva untuk segera dikonversikan ke dalam kas dengan sedikit atau tanpa penurunan nilai, serta tingkat kepastian tentang jumlah kas yang diperoleh. Rasio likuiditas merupakan rasio yang digunakan untuk mengukur tingkat kemampuan suatu perusahaan dalam memenuhi kewajiban keuangan yang berjangka pendek tepat pada waktunya.

Tingkat likuiditas yang tinggi memperkecil kegagalan perusahaan dalam memenuhi kewajiban finansial jangka pendek kepada kreditur dan belaku pula sebaliknya. Tinggi rendahnya rasio ini akan mempengaruhi minat investor untuk menginvestasikan dananya. Makin besar rasio ini maka makin efesien perusahaan dalam mendayagunakan aktiva lancar perusahaan (Rompas, 2013:253).

Penurunan nilai perusahaan pada beberapa tahun belakangan ini dapat dipengaruhi oleh beberapa faktor. Faktor-faktor perusahaan yang dapat mempengaruhi nilai perusahaan antara lain profitabilitas, struktur modal, dan likuiditas. Berdasarkan latar belakang masalah dan uraian diatas, maka perlu dilakukan penelitian tentang "Determinan Nilai Perusahaan (Studi pada bank umum yang terdaftar di BEI Periode 2015-2019)".

Adapun tujuan penelitian ini adalah untuk mengetahui dan mengkaji kondisi profitabilitas, struktur modal, dan likuiditas terhadap nilai perusahaan pada bank umum yang terdaftar di BEI periode 2015-2019 serta seberapa besar dari ketiga faktor tersebut berpengaruh terhadap nilai perusahaan.

\section{METODE PENELITIAN}

\section{Jenis Penelitian}

Metode penelitian merupakan cara utama yang digunakan peneliti untuk mencapai tujuan sesuai dengan kebutuhan. Menurut (Sugiyono, 2013:2), metode penelitian adalah cara 
imiah untuk mendapatkan data dengan tujuan dan kegunaan tertentu. Penelitian ini menggunakan metode verifikatif untuk menguji seberapa jauh tujuan itu tercapai sesuai teori yang sudah ada. Menurut Moch. Nazir (2011:91), metode verifikatif adalah metode yang bertujuan untuk mengetahui hubungan kausalitas antar variabel melalui suatu pengujian hipotesis melalui suatu perhitungan statistik sehingga didapat hasil pembuktian yang menunjukan hipotesis diterima atau ditolak.

Penelitian ini merupakan penelitian mengenai Pengaruh Profitabilitas, Struktur Modal, dan Likuiditas terhadap Nilai Perusahaan (Studi pada bank umum yang terdaftar di Bursa Efek Indonesia Periode 2015-2019). Penelitian ini dimulai dengan menggunakan analisis rasio profitabilitas (ROE) sebagai variabel $\mathrm{X}_{1}$. Kemudian rasio struktur modal (DER) sebagai variabel $\mathrm{X}_{2}$. Selanjutnya rasio likuiditas (LDR) sebagai variable $\mathrm{X}_{3}$. Dan terakhir menggunakan analisis nilai perusahaan yang diproksikan dengan Price Book Value (PBV) variabel Y.

Penelitian ini menggunakan variabel dependen dan variabel independen. Variabel dependen adalah variabel yang di pengaruhi atau yang menjadi akibat karena adanya perubahan variabel independen, sedangkan variabel independen adalah variabel yang mempengaruhi variabel dependen. Variabel dependen dalam penelitian ini adalah nilai perusahaan. Variabel independen pada penelitian ini adalah profitabilitas, struktur modal dan likuiditas.

\section{Waktu dan Tempat Penelitian}

Untuk waktu dan tempat penelitian, penulis mengambil data sekunder yaitu laporan keuangan pada Bank Umum yang terdaftar di Bursa Efek Indonesia periode tahun 20152019 melalui website www.idx.co.id.

\section{Subjek Penelitian}

Pengertian populasi menurut (Sugiyono, 2013:115) adalah wilayah generalisasi yang terdiri atas objek atau subyek yang mempunyai kualitas dan karakteristik tertentu yang ditetapkan oleh peneliti untuk dipelajari dan kemudian ditarik kesimpulannya. Populasi dalam penelitian ini meliputi bank umum yang telah terdaftar di Bursa Efek Indonesia tahun 2015-2019.

Sampel menurut (Sugiyono, 2013:116) adalah bagian dari jumlah dan karakteristik yang dimiliki oleh populasi tersebut. Sampel dalam penelitian ini adalah sebanyak 32 bank umum yang telah terdaftar di Bursa Efek Indonesia tahun 2015-2019.

Jenis data dalam penelitian ini adalah kuantitatif. Menurut Sugiyono (2013:15) data kuantitatif adalah jenis data yang dapat diukur atau dihitung secara langsung, yang berupa informasi atau penjelasan yang dinyatakan dengan bilangan atau berbentuk angka. Untuk 
waktu pengumpulannya yaitu data time series. Data time series adalah data satu entitas dengan dimensi waktu/periode yang panjang atau tidak satu waktu/periode.

Dimana teknik samplingnya yaitu dari 32 bank umum yang terdaftar di BEI tahun 20152019 dengan periode selama 5 tahun, data tersebut dikompilasi yaitu sebanyak 128 data sampling.

\section{Prosedur Penelitian}

Dalam melakukan suatu penelitian ilmiah, peneliti harus mengikuti aturan-aturan metode ilmiah yang ada. Untuk menerapkan metode ilmiah dalam penelitian maka diperlukan suatu desain penelitian. Desain penelitian ini sendiri harus mengikuti metode penelitian. (Arikunto, 2006:51) mengemukakan bahwa "desain penelitian adalah rencana atau rancangan yang dibuat oleh peneliti sebagai rancangan kegiatan yang akan dilaksanakan.” Desain penelitian merupakan tipe penelitian yang akan dilakukan dan tergantung pada jenis masalah. Menurut (Iqbal Hasan, 2002:32) ada tiga jenis desain penelitian, yaitu:

1. Desain Eksplanatori

Desain eksplanatori berusaha mencari ide-ide atau hubungan-hubungan yang baru, sehingga dapat dikatakan desain ini bertitik tolak dari variabel, bukan dari fakta.

2. Desain Deskriptif

Desain ini bertujuan untuk menguraikan sifat atau karakteristik dari suatu fenomena tertentu.

\section{Desain Kausal}

Desain kausal berguna untuk menganalisis hubungan-hubungan antara satu variabel dengan variabel lainnya atau bagaimana suatu variabel mempengaruhi variabel lainnya. Desain kausal menguji hubungan "sebab akibat", menurut (Sugiyono, 2013:56) metode kausal adalah "hubungan yang bersifat sebab akibat, jadi disini ada variabel independen (variabel yang mempengaruhi) dan variabel dependen (dipengaruhi)". Menurut (Uma dan Roger, 2017:112) dalam studi kausal peneliti tertarik untuk menjelaskan satu atau lebih banyak faktor yang menyebabkan masalah, dengan kata lain, maksud peneliti untuk melukan studi kausal adalah agar mampu menyatakan bahwa variabel $\mathrm{X}$ menyebabkan variabel Y.

Berdasarkan penjelasan yang ada, maka desain yang digunakan dalam penelitian ini adalah desain kausal. Desain penelitian kausal sering juga disebut sebagai desain kausal komparatif. Desain kausal komparatif digunakan untuk menjelaskan hubungan kausal antar variabel melalui pengujian hipotesis. Desain kausal komparatif mengkaji secara mendalam 
dan menyeluruh hubungan sebab akibat sekaligus untuk mencari tahu bagaimana keterkaitan antara variabel dan masalahnya yang merujuk pada tujuan penelitian.

Variabel dependen dalam penelitian ini adalah nilai perusahaan. Variabel independen pada penelitian ini adalah profitabilitas, struktur modal dan likuiditas.

Dalam rangka mendapatkan konsep pengukuran yang jelas dan mengindarkan persepsi yang berbeda-beda tentang variabel yang diteliti, maka diperlukan adanya operasionalisasi variabel. Operasionalisasi variabel adalah unsur penelitian yang memberitahukan bagaimana cara mengukur suatu variabel, yang bertujuan untuk membantu peneliti lain yang ingin menggunakan variabel yang sama. Definisi operasional masing-masing variabel adalah sebagai berikut :

1. Nilai perusahaan adalah harga pasar saham perusahaan yang merupakan indikator untuk mengukur pandangan investor terhadap kinerja perusahaan. Nilai perusahaan didasarkan pada price book value (PBV). Prive book value dihitung dengan rumus (Wulandari, 2014:459) ialah

$$
P B V=\frac{\text { Harga pasar saham }}{\text { Nilai buku per lembar saham }} \times 100 \%
$$

2. Profitabilitas merupakan kemampuan perusahaan menghasilkan laba. Rasio profitabilitas yang digunakan dalam penelitian ini adalah Return on Equity (ROE). Return on equity (ROE) dihitung dengan rumus (Suharli, 2006:28) ialah

$$
R O E=\frac{\text { Laba Bersih Setelah Pajak }}{\text { Jumlah Aktiva Bersih Perusahaan }}
$$

3. Struktur modal merupakan perbandingan antara hutang dan ekuitas. Struktur modal dalam penelitian ini di ukur dengan Debt to Equity Ratio (DER). DER dihitung dengan rumus (Camelia, 2011:217) ialah

$$
D E R=\frac{\text { Total Debt }}{\text { Total Assets }}
$$

4. Likuiditas adalah tingkat kemampuan suatu perusahaan untuk dapat membayar hutanghutangnya yang telah jatuh tempo. Likuiditas dalam penelitian ini di ukur dengan Loan to Deposit Ratio (LDR). LDR dihitung dengan rumus (Putu Yunita et al, 2014:3) ialah

$$
L D R=\frac{\text { Jumlah Kredit }}{\text { Dana Pihak Ketiga }} \times 100 \%
$$




\section{Data, Instrumen, dan Teknik Pengumpulan Data}

Jenis data dalam penelitian ini adalah kuantitatif. Menurut Sugiyono (2013:15) data kuantitatif adalah jenis data yang dapat diukur atau dihitung secara langsung, yang berupa informasi atau penjelasan yang dinyatakan dengan bilangan atau berbentuk angka. Untuk waktu pengumpulannya yaitu data time series. Data time series adalah data satu entitas dengan dimensi waktu/periode yang panjang atau tidak satu waktu/periode.

Berdasarkan permasalahan yang diteliti dan sesuai dengan judul dalam penelitian ini yaitu determinan nilai perusahaan pada bank umum yang terdaftar di BEI Tahun 20152019. Sedangkan untuk alat analisis yang digunakan yaitu berupa laporan keuangan bank dan yang menjadi sub-variabelnya adalah $\mathrm{X}_{1}, \mathrm{X}_{2}$ dan $\mathrm{X}_{3}$ pada rasio-rasio keuangan, yang menjadi indikatornya adalah untuk $\mathrm{X}_{1}$ yaitu Profitabilitas (ROE), untuk $\mathrm{X}_{2}$ yaitu Struktur Modal (DER) dan untuk $\mathrm{X}_{3}$ yaitu Likuiditas (LDR). Untuk tabel instrumen penelitian disajikan sebagai berikut:

Tabel 3.1

\section{Instrumen Penelitian}

\begin{tabular}{|c|c|c|c|}
\hline Variabel & Konsep Variabel & Pengukuran & Skala \\
\hline $\begin{array}{l}\text { Profitabilitas } \\
\qquad\left(\mathrm{X}_{1}\right)^{*}\end{array}$ & $\begin{array}{l}\text { Profitabilitas merupakan } \\
\text { kemampuan perusahaan } \\
\text { menghasilkan laba. Rasio } \\
\text { profitabilitas yang digunakan } \\
\text { dalam penelitian ini adalah } \\
\text { Return on Equity (ROE). } \\
\text { (Suharli, 2006:28) }\end{array}$ & $\begin{array}{c}\frac{\text { Laba Bersih Setelah Paja }}{\text { Rata - rata ekuitas }} \\
(\text { Suharli, 2006:28) }\end{array}$ & Rasio \\
\hline $\begin{array}{l}\text { Struktur } \\
\text { Modal } \\
\left(\mathrm{X}_{2}\right)^{* * *}\end{array}$ & $\begin{array}{l}\text { Struktur modal merupakan } \\
\text { perbandingan antara hutang } \\
\text { dan ekuitas. Struktur modal } \\
\text { dalam penelitian ini di ukur } \\
\text { dengan Debt to Equity Ratio } \\
\text { (DER). } \\
\text { (Camelia, 2011:217) }\end{array}$ & $\begin{array}{c}\frac{\text { Total Debt }}{\text { Total Equity }} \\
\text { (Camelia, 2011:217) }\end{array}$ & Rasio \\
\hline
\end{tabular}




\begin{tabular}{|c|c|c|c|}
\hline $\begin{array}{c}\text { Likuiditas } \\
\left(\mathrm{X}_{3}\right)^{* * *}\end{array}$ & $\begin{array}{l}\text { Likuiditas adalah tingkat } \\
\text { kemampuan suatu perusahaan } \\
\text { untuk dapat membayar } \\
\text { hutang-hutangnya yang telah } \\
\text { jatuh tempo. Likuiditas dalam } \\
\text { penelitian ini di ukur dengan } \\
\text { Loan to Deposit Ratio (LDR). } \\
\text { (Putu Yunita et al, 2014:3) }\end{array}$ & $\begin{array}{l}\frac{\text { Jumlah Kredit }}{\text { Dana Pihak Ketiga }} \times 100 \% \\
\text { (Putu Yunita et al, 2014:3) }\end{array}$ & Rasio \\
\hline $\begin{array}{c}\text { Nilai } \\
\text { Perusahaan } \\
(\mathrm{Y})^{* * * *}\end{array}$ & $\begin{array}{l}\text { Nilai perusahaan adalah harga } \\
\text { pasar saham perusahaan yang } \\
\text { merupakan indikator untuk } \\
\text { mengukur } \\
\text { pandangan investor terhadap } \\
\text { kinerja perusahaan. Nilai } \\
\text { perusahaan didasarkan pada } \\
\text { price book value (PBV). } \\
\text { (Wulandari, 2014:459) }\end{array}$ & $\begin{array}{c}\text { Harga pasar saham } \\
\text { Nilai buku per lembar saha } \\
\text { (Dwi, 2014:459) }\end{array}$ & Rasio \\
\hline
\end{tabular}

Teknik pengumpulan data yang digunakan untuk memperoleh data dalam pembuatan tesis ini sebagai berikut:

1. Studi kepustakaan, yaitu dengan cara menggunakan data dari buku-buku dan sumber-sumber data lainnya yang berhubungan dengan masalah yang dibahas.

2. Observasi sebagai teknik pengumpulan data yaitu dengan cara menggunakan internet untuk mencari data-data yang dibutuhkan dalam penelitian.

\section{Teknik Analisis Data}

Dari adanya permasalahan dalam penurunan nilai perusahaan, penelitian ini bertujuan untuk mengidentifikasi dinamika profitabilitas, likuiditas, dan struktur modal pada bank umum yang terdaftar di BEI periode 2015-2019, mengidentifikasi pengaruhnya dan memformulasikan implikasi manajerial dan merekomendasi kesimpulan bahwa ada pengaruh dari Return on Equity (ROE), Debt To Equity Ratio (DER), dan Loan To Deposit Ratio (LDR) terhadap Price To Book Value (PBV).

\section{Uji Keabsahan Data}


Sebelum melakukan pengujian hipotesis, diperlakukan pengujian validitas dan reliabilitas terhadap indikator atau pertanyaan-pertanyaan kuesioner dengan menggunakan spss version 23. Nilai yang digunakan untuk menentukan kevalidan item adalah pada corrected item-total correlation. Apabila nilainya $>\mathrm{r}_{\text {tabel}}$, maka item valid. Keajegan dalam cronbach alpha harus $>$ dari $r_{\text {tabel }}$ indentifikasi bahwa reliabitas cukup. Penelitian ini menggunakan data sekunder, maka untuk menentukan ketepatan model perlu dilakukan pengujian atas beberapa asumsi klasik yang digunakan dalam penelitian ini. Pengujian asumsi klasik dilakukan dengan melakukan uji normalitas, uji heteroskedastisitas, uji multikolinieritas, dan uji auto korelasi. Sebelum pengujian asumsi klasik dilakukan, terlebih dahulu akan dilakukan pengujian normalitas errors. Pengujian normalitas bertujuan untuk mengetahui apakah dalam model regresi, variabel pengganggu atau residual memiliki distribusi normal. Hal ini dilakukan mengingat bahwa uji t dan F mengasumsikan bahwa nilai residual mengikuti distribusi normal.

\section{Uji Normalitas}

Menurut Priyatno (2010:71), Uji normalitas digunakan untuk mengetahui apakah populasi berdistribusi normal atau tidak. Jika analisis menggunakan metode parametrik, maka persyaratan normalitas harus terpenuhi, yaitu data berasal dari distribusi yang normal. Uji normalitas dilakukan pada nilai residualnya bukan pada nilai masing-masing variabel. Uji normalitas dilakukan dengan menggunakan one-sample Kolmogorov-Smirnov Test. Apabila tingkat signifikansi lebih besar dari nilai $\alpha$ (5\%) maka dapat dikatakan bahwa residual sudah terdistribusi secara normal. Namun apabila sebaliknya tingkat signifikansi lebih kecil dari nilai $\alpha$ (5\%), maka dapat dikatakan bahwa residual belum terdistribusi secara normal.

\section{Uji Heterokedastisitas}

Uji heteroskedastisitas bertujuan utuk menguji apakah model regresi terjadi ketidaksamaan varian dari residual suatu pengamatan ke pengamatan yang lain. Jika pada varian dari residual pada suatu pengamatan kepengamatan yang lain sama, maka disebut homoskedastisitas dan jika berbeda disebut heteroskdastisitas. Uji heteroskedastisitas dalam penelitian ini dilakukan melalui metode scatterplot, yaitu mengamati pola titiktitiknya. Jika titik-titik scatterplot menyebar di atas dan dibawah angka 0 pada sumbu $\mathrm{Y}$ dan tidak membentuk pola tertentu, maka dapat dikatakan bahwa tidak terjadi masalah heteroskedastisitas. (Lubis, 2016:34).

\section{Uji Multikolinearitas}

Menurut Ghozali (2006:105), Uji Multikolinearitas bertujuan untuk menguji apakah model regresi ditemukan adanya korelasi antar variabel bebas (Independen). Model 
korelasi yang baik seharusnya tidak terjadi korelasi di antara variabel independen. Jika variabel independen saling berkorelasi maka variabel ini tidak ontogonal. Variebel ontogonal adalah variabel independen yang nilai korelasi antar sesama variabel independen sama dengan nol.Untuk mendeteksi adanya multikolonieritas dengan membuat hipotesis:

a. Tolerance value $<0,10$ atau VIF $>10$ : terjadi multikolinearitas

b. Tolerance value $>0,10$ atau VIF $<10$ : tidak terjadi multikolinearitas

\section{Uji Auto Korelasi}

Autokorelasi adalah keadaan dimana terjadinya korelasi antara residual pada satu pengamatan dengan pengamatan lain pada model regresi. Metode pengujian menggunakan uji Durbin-Watson (uji DW) dengan ketentuan sebagai berikut: (Priyatno, 2010:81)

a. Jika d lebih kecil dari dl atau lebih besar dari 4-dl, maka hipotesis nol ditolak, yang berarti terdapat autokorelasi.

b. Jika d terletak antara du dan 4-du, maka hipotesis nol diterima yang berarti tidak ada autokorelasi.

c. Jika d terletak antara dl dan du atau 4-du dan 4-dl, maka tidak menghasilkan kesimpulan yang pasti.

\section{Rancangan Analisis Dan Uji Hipotesis}

\section{Analisis Deskriptif}

Pengertian metode deskriptif analisis menurut Sugiyono (2013:134) adalah statistika yang digunakan untuk menganalisa data dengan cara mendeskripsikan atau menggambarkan data yang telah terkumpul sebagaimana adanya tanpa bermaksud membuat kesimpulan yang berlaku untuk umum atau generalisasi. Analisis deskriptif merupakan analisis yang bertujuan menggambarkan serta menjelaskan tentang variabel yang dteliti dengan cara mengumpulkan data, mengolah, menganalisis, dan menginterpretasinya data sehingga dapat memberikan gambaran keadaan perusahaan secara nyata untuk kemudian bisa dijadikan dasar untuk mengajukan saran-saran perbaikan.

\section{Analisis Verifikatif (Analisis Regresi Berganda)}

Pengujian koefesien regresi keseluruhan menunjukan apakah variabel bebas secara keseluruhan atau bersama mempunyai pengaruh terhadap variabel terikat (Rompas, 2013:257). Menurut Alghifari (dalam Rompas, 2013:257) Pengujian terhadap hipotesis dalam penelitian ini menggunakan analisis regresi berganda. Analisis regresi berganda digunakan untuk menguji pengaruh antara variabel independen terhadap nilai perusahaan sebagai variabel dependen. Persamaan regresi dapat dituliskan sebagai berikut : 


$$
Y=a=b(\text { it }) X_{1}(\text { it })+b(\text { it }) X_{2}(\text { it })+b(\text { it }) X_{3}(\text { it })+e(i t)
$$

Keterangan :

$$
\begin{array}{ll}
\mathrm{Y} & =\text { PBV (variabel dependen) } \\
\mathrm{X}_{1} & =\mathrm{ROE} \text { (variabel independen) } \\
\mathrm{X}_{2} & =\text { DER (variabel independen) } \\
\mathrm{X}_{3} & =\mathrm{LDR} \text { (variabel independen) } \\
\mathrm{i} & =\text { Sampel } \\
\mathrm{t} & =\text { Tahun } \\
\mathrm{a} & =\text { Konstanta } \\
\mathrm{b} & =\text { Koefesien regresi } \\
\mathrm{e} & =\text { Error term }
\end{array}
$$

\section{Uji Koefisien Determinasi}

Menurut Ghozali (dalam Putu Yunita et al, 2007:4) Dalam analisis korelasi terdapat suatu angka yang disebut dengan koefisien determinasi atau yang sering disebut dengan koefisien penentu, karena besarnya adalah kuadrat dari koefisien korelasi $\left(\mathrm{r}^{2}\right)$, sehingga koefisien ini berguna untuk mengetahui besarnya kontribusi pengaruh variabel $\mathrm{X}$ terhadap variabel $\mathrm{Y}$.

Oleh karena itu, Untuk menentukan besarnya kontribusi suatu variabel independen $\left(\mathrm{X}_{1}, \mathrm{X}_{2}, \mathrm{X}_{3}\right)$ terhadap variabel dependen $(\mathrm{Y})$ digunakan koefisien determinasi, yang akan dihitung dengan menggunakan rumus:

$$
\mathrm{Kd}=\mathrm{r}^{2} \times 100 \%
$$

Dimana: $\mathrm{Kd}=0$, berarti pengaruh variabel $\mathrm{X}$ terhadap variabel $\mathrm{Y}$ lemah.

$\mathrm{Kd}=1$, berarti pengaruh variabel $\mathrm{X}$ terhadap variabel $\mathrm{Y}$ kuat.

Keterangan: $\mathrm{Kd}=$ Koefisien Determinasi

$$
\mathrm{r}^{2}=\text { Koefisien Korelasi }
$$

\section{Uji Hipotesis}

\section{Uji Regresi Simultan (Uji F)}

Uji Statistik F menunjukkan apakah semua variabel independen yang dimasukan dalam model mempunyai pengaruh secara bersama-sama terhadap variabel dependen. 
1. Jika nilai profitabilitas < 0 maka ini berarti bahwa secara simultan semua variabel independen tersebut tidak mempunyai pengaruh yang negatif terhadap variabel dependen, begitu juga sebaliknya.

2. Jika nilai profitabilitas di bawah $5 \%$, maka ini berarti bahwa variabel independen yang digunakan adalah variabel yang secara signifikan penting dalam mempengaruhi variabel dependen.

Uji hipotesis untuk mendeskripsikan ketiga variabel sebagai berikut :

\section{a. Pengaruh Profitabilitas $\left(\mathrm{X}_{1}\right)$ terhadap Nilai Perusahaan (Y)}

Hipotesis bentuk statistik:

$\mathrm{H} 0: \mathrm{b}_{1} \mathrm{X}_{1}=0$ (tidak ada pengaruh)

$\mathrm{Ha}: \mathrm{b}_{1} \mathrm{X}_{1} \neq 0$ (ada pengaruh)

Hipotesis bentuk kalimat:

H0 : Profitabilitas tidak berpengaruh terhadap Nilai Perusahaan

Ha : Profitabilitas berpengaruh terhadap Nilai Perusahaan

\section{b. Pengaruh Struktur Modal $\left(\mathbf{X}_{2}\right)$ Terhadap Nilai Perusahaan (Y)}

Hipotesis bentuk statistik:

$\mathrm{H} 0: \mathrm{b}_{2} \mathrm{X}_{2}=0$ (tidak ada pengaruh)

$\mathrm{Ha}: \mathrm{b}_{2} \mathrm{X}_{2} \neq 0$ (ada pengaruh)

Hipotesis bentuk kalimat:

H0 : Struktur modal tidak berpengaruh terhadap Nilai Perusahaan

Ha : Struktur modal berpengaruh terhadap Nilai Perusahaan

\section{c. Pengaruh Likuiditas $\left(\mathbf{X}_{3}\right)$ Terhadap Nilai Perusahaan (Y)}

Hipotesis bentuk statistik:

$\mathrm{H} 0: \mathrm{b}_{3} \mathrm{X}_{3}=0$ (tidak ada pengaruh)

Ha: $b_{3} X_{3} \neq 0$ (ada pengaruh)

Hipotesis bentuk kalimat:

H0 : Likuiditas tidak berpengaruh terhadap Nilai Perusahaan

Ha : Likuiditas berpengaruh terhadap Nilai Perusahaan

\section{Uji Regresi Parsial (Uji T)}

Pengujian untuk mengetahui penolakan atau penerimaan hipotesis dilakukan dengan kriteria sebagai berikut: 
1.Jika profitabilitas > 0,05 maka hipotesis ditolak (Koefisien regresi tidak signifikan). Ini berarti bahwa secara parsial variabel independen tidak mempunyai pengaruh signifikan terhadap variabel dependen.

2.Jika profitabilitas < 0,05 maka hipotesis tidak dapat ditolak (koefesien regresi signifikan). Ini berarti bahwa secara parsial variabel independen mempunyai pengaruh signifikan terhadap variabel dependen.

Uji hipotesis untuk mendeskripsikan ketiga variabel sebagai berikut :

a. Pengaruh Profitabilitas $\left(\mathbf{X}_{1}\right)$, Struktur Modal $\left(\mathbf{X}_{2}\right)$, dan Likuiditas $\left(\mathbf{X}_{3}\right)$ terhadap Nilai Perusahaan (Y)

Hipotesis bentuk statistik:

HO: $b_{1,3}=0$ (tidak ada pengaruh)

Ha: $b_{1,3} \neq 0$ (ada pengaruh)

Hipotesis bentuk kalimat:

H0 : Pengaruh Profitabilitas $\left(X_{1}\right)$, Struktur Modal $\left(X_{2}\right)$, dan Likuiditas $\left(X_{3}\right)$ secara simultan tidak berpengaruh terhadap Nilai Perusahaan

Ha : Pengaruh Profitabilitas $\left(X_{1}\right)$, Struktur Modal $\left(X_{2}\right)$, dan Likuiditas $\left(X_{3}\right)$ secara simultan berpengaruh terhadap Nilai Perusahaan.

\section{HASIL PENELITIAN DAN PEMBAHASAN}

\section{Hasil Penelitian}

\section{Hasil Pengujian Keabsahan Data}

\section{Uji Normalitas}

1. Analisis Grafik

Pada analisis grafik yang dilakukan dapat terlihat gambar normal probability plot yang menunjukan bahwa data menyebar disekitar garis diagonal dan mengikuti arah garis diagonal dan menunjukan pola distribusi normal, sehingga dapat disimpulkan bahwa asumsi normalitas telah terpenuhi sehingga model regresi dalam penelitian ini layak untuk digunakan.

2. Analisis Statistik

Berikut hasil uji Kolmogorov-Smirnov (K-S) yang terlihat :

Nilai Perusahaan (Asymp. Sig. (2-tailed) pada table 4.2 untuk variabel sebesar $0,460>0,05$ yang berarti residual terdistribusi secara normal.

\section{Uji Asumsi Klasik}

\section{Uji Multikolinearitas}


Dari hasil tabel 4.2 dapat diketahui nilai Variance Inflation Factor (VIF) dan tolerance (TOL) sebagai berikut:

1. Variabel ROE memiliki nilai VIF sebesar 1,426 lebih kecil dari 10 dan nilai TOL sebesar 0,701 lebih besar dari 0,10, sehingga variabel ROE dinyatakan tidak ada multikolinearitas.

2. Variabel DER memiliki nilai VIF sebesar 1,007 lebih kecil dari 10 dan nilai TOL sebesar 0,993 lebih besar dari 0,10, sehingga variabel DER dinyatakan tidak ada multikolinearitas.

3. Variabel LDR memiliki nilai VIF sebesar 1,434 lebih kecil dari 10 dan nilai TOL sebesar 0,697 lebih besar dari 0,10, sehingga variabel LDR dinyatakan tidak ada multikolinearitas.

Dari ketiga variabel independen di atas dinyatakan bahwa tidak ada multikolinearitas antar variabel independen dalam model regresi.

\section{Uji Heterokedastisitas}

\section{Gambar 4.2}

Hasil Scatter Plot

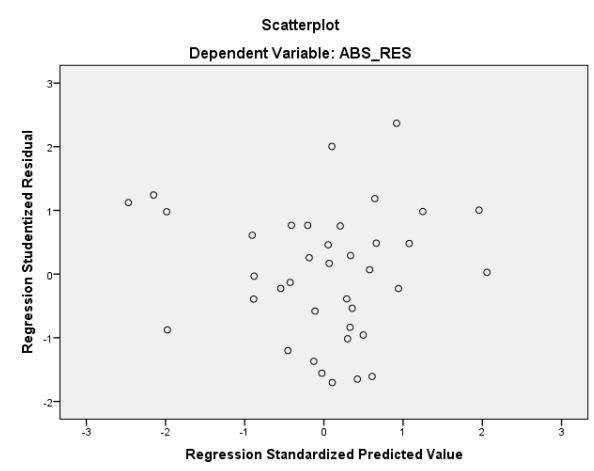

Sumber: Diolah dengan SPSS (2020)

Berdasarkan hasil uji Scatter Plot diatas bahwa titik-titik menyebar dan tidak membentuk pola tertentu yang jelas. Sehingga dapat disimpulkan bahwa tidak terjadi heterokedastisitas.

\section{Uji Autokorelasi}

Salah satu cara untuk dapat mendeteksi ada atau tidaknya autokorelasi adalah dengan uji Durbin-Watson. Berikut adalah hasil uji Durbin-Watson :

Berdasarkan output di atas diketahui bahwa nilai DW 2.213, dengan nilai tabel signifikansi $5 \%$, jumlah sampel $\mathrm{N}=190$ dan jumlah variabel independen $3(\mathrm{~K}=3)$ maka diperoleh nilai du $=$ 1.6563, sedangkan nilai dl sebesar 2.3437. 


\section{Analisis Deskriptif}

Data deskriptif digunakan untuk menunjukan jumlah data dalam penelitian ini, nilai minimum, nilai maksimum, nilai rata-rata (mean), dan nilai standar deviasi dari masing-masing variabel dalam penelitian yaitu PBV, ROE, DER, dan LDR.

Tabel 4.5 di atas menunjukan bahwa jumlah data yang digunakan dalam penelitian ini berjumlah 190 data selama periode pengamatan tahun 2013 sampai tahun 2017. Variabel ROE memiliki nilai minimum $-52,07$, nilai maksimum 21,88 , dan nilai rata-rata 5,9837 . Variabel DER memiliki nilai minimum 3,44, nilai maksimum 10,89, dan nilai rata-rata 6,6216. Variabel LDR memiliki nilai minimum 51,75, nilai maksimum 112,13, dan nilai rata-rata 84,4371 .

Tabel 4.5 di atas menunjukan bahwa jumlah data yang digunakan dalam penelitian ini berjumlah 190 data selama periode pengamatan (2013 sampai 2017). Variabel PBV memiliki nilai minimum 0,33 , nilai maksimum 3,85 , dan nilai rata-rata 1,7029 .

\section{Analisis Verifikatif dan Uji Hipotesis}

\section{Analisis Verifikatif}

Berdasarkan uji T dari variabel independen (ROE, DER, dan LDR) terhadap variabel dependen (PBV) dapat dilihat pada tabel 4.6

Pengujian secara parsial variabel ROE terhadap PBV pada tabel 4.6 diperoleh nilai t-hitung sebesar 2,056 dan nilai perusahaan signifikansi 0,048. Dimana nilai perusahaan signifikansi 0,048 ini signifikan pada tingkat signifikansi 0,05 karena lebih besar dari 0,05. Sehingga dapat disimpulkan bahwa ROE berpengaruh secara positif dan signifikan terhadap PBV.

Pengujian secara parsial variabel DER terhadap PBV pada tabel 4.6 diperoleh nilai thitung sebesar -2,195 dan nilai perusahaan signifikansi 0,035. Dimana nilai perusahaan signifikansi 0,035 ini signifikan pada tingkat signifikansi 0,05 karena lebih besar dari 0,05. Sehingga dapat disimpulkan bahwa DER berpengaruh secara positif dan signifikan terhadap PBV.

Pengujian secara parsial variabel LDR terhadap PBV pada tabel 4.6 diperoleh nilai thitung sebesar 2,169 dan nilai perusahaan signifikansi 0,037. Dimana nilai perusahaan signifikansi 0,037 ini signifikan pada tingkat signifikansi 0,05 karena lebih besar dari 0,05. Sehingga dapat disimpulkan bahwa LDR berpengaruh secara positif dan signifikan terhadap PBV.

Untuk mengetahui pengaruh simultan variabel ROE, DER, dan LDR terhadap PBV pada bank konvensional yang terdaftar di Bursa Efek Indonesia maka dilakukan Uji F. Perhitungan hasil Uji F pada tabel 4.7 di atas diperoleh nilai F-hitung sebesar 7,726 dan nilai 
signifikansi sebesar 0,000. Dimana nilai profitabilitas signifikansi 0,000 ini signifikansi pada tingkat signifikansi 0,05 karena lebih kecil dari 0,05, maka model regresi dapat digunakan untuk memprediksi PBV atau dapat dikatakan variabel ROE, DER, dan LDR secara bersamasama berpengaruh terhadap PBV.

\section{Analisis Regresi Berganda}

Berikut adalah hasil analisa pengaruh ROE, DER, dan LDR terhadap PBV dilakukan dengan menggunakan analisis linear berganda dengan menggunakan SPSS yang dapat dilihat pada tabel 4.8.

Dari hasil analisis regresi linear berganda pada tabel 4.8 di atas bahwa variabel ROE, DER, dan LDR memiliki signifikansi karena dibawah 0,05 yang dalam hal ini nilai perusahaan signifikansi ROE sebesar 0,048, nilai perusahaan signifikansi DER $=0,035$, dan nilai perusahaan signifikansi $\mathrm{LDR}=0,037$.

Dari tabel 4.8 dapat disimpulkan bahwa disusun persamaan regresi linear berganda dengan persamaan matematis sebagai berikut:

$$
\begin{aligned}
& Y=a=b(i t) X_{1}(i t)+b(i t) X_{2}(i t)+b(i t) X_{3}(i t)+e(i t) \\
& Y=0,430+0,024 \times 1+(-0,123) \times 2+0,023 \times 3 .
\end{aligned}
$$

\section{PBV = 0,430 + 0,024 ROE + (-0,123) DER + 0,023 LDR}

Berdasarkan hasil persamaan regresi linear berganda di atas dapat dijelaskan bahwa:

a. Konstanta sebesar 0,430 menyatakan bahwa jika variabel independen (ROE, DER, dan LDR) dianggap konstan, maka rata-rata PBV 0,430.

b. Koefisien regresi ROE sebesar 0,024 menyatakan bahwa setiap kenaikan ROE sebesar satu satuan dan kondisi DER dan LDR pada posisi stabil (tidak berubah), maka variabel PBV akan mengalami penurunan 0,024 kalinya atau sebaliknya.

c. Koefisien regresi DER sebesar -0,123 menyatakan bahwa setiap kenaikan DER sebesar satu satuan dan kondisi ROE dan LDR pada posisi stabil (tidak berubah), maka variabel PBV akan mengalami penurunan -0,123 kalinya atau sebaliknya.

Koefesien regresi LDR sebesar 0,023 menyatakan bahwa setiap kenaikan LDR sebesar satu satuan dan kondisi ROE dan DER pada posisi stabil (tidak berubah), maka variabel PBV akan mengalami penurunan 0,023 kalinya atau sebaliknya.

\section{Analisis Koefisien Determinasi $\left(\mathbf{R}^{2}\right)$}

Berdasarkan tabel 4.9, hasil output pengolahan data dapat dijelaskan sebagai berikut: Multiple regression (r) sebesar 0,637, artinya korelasi antara variabel ROE,DER, dan LDR dengan PBV adalah positif 0,637. Membuktikan bahwa hubungan variabel ROE, DER, dan LDR dengan PBV adalah kuat. 
Untuk mengukur seberapa jauh kemampuan model dalam menerangkan variabel-variabel dependen maka digunakan koefisien determinasi $\left(R^{2}\right)$. Nilai $R^{2}$ adalah sebesar 0,637 , hal ini menjelaskan bahwa kontribusi yang diberikan variabel ROE, DER, dan LDR terhadap PBV sebesar $63,7 \%$ sedangkan sisanya $36,3 \%$ dipengaruhi oleh faktor-faktor lainnya yang tidak diteliti.

\section{Uji Hipotesis}

Uji hipotesis dilakukan dengan melakukan uji $\mathrm{T}$ dan uji $\mathrm{F}$. Untuk mengetahui pengaruh secara parsial variabel ROE, DER, dan LDR terhadap PBV maka dilakukan uji T dengan hasil pengujian seperti pada tabel 4.10, adapun untuk mengetahui pengaruh secara simultan variabel ROE, DER, dan LDR terhadap PBV maka dilakukan uji F.

\section{Uji T}

Pada tabel 4.12 dijelaskan bahwa hasil uji t menyatakan bahwa variabel ROE memiliki t hitung 2,056 dengan probabilitas signifikan 0.048. dimana nilai probabilitas signifikansi 0,048 ini signifikan pada tingkat signifikansi 0,05 karena lebih kecil dari 0,05. Sehingga dapat disimpulkan bahwa ROE berpengaruh secara positif dan signifikan terhadap PBV sebesar 20,25\%. Sehingga hipotesis 1 yang menyatakan bahwa ROE berpengaruh positif dan signifikan terhadap PBV diterima. Perhitungan tersebut menunjukan bahwa pengaruh signifikan variabel ROE terhadap variabel PBV secara parsial berpengaruh positif dan signifikan.

Pada tabel 4.12 dijelaskan bahwa hasil uji t menyatakan bahwa variabel DER memiliki t hitung -2,195 dengan probabilitas signifikan 0.035. dimana nilai probabilitas signifikansi 0,035 ini signifikan pada tingkat signifikansi 0,05 karena lebih kecil dari 0,05. Sehingga dapat disimpulkan bahwa DER berpengaruh secara positif dan signifikan terhadap PBV sebesar 10,08\%. Sehingga hipotesis 2 yang menyatakan bahwa DER berpengaruh positif dan signifikan terhadap PBV diterima. Perhitungan tersebut menunjukan bahwa pengaruh signifikan variabel DER terhadap variabel PBV secara parsial berpengaruh positif dan signifikan.

Pada tabel 4.12 dijelaskan bahwa hasil uji t menyatakan bahwa variabel LDR memiliki t hitung 2,169 dengan probabilitas signifikan 0.037. dimana nilai probabilitas signifikansi 0,037 ini signifikan pada tingkat signifikansi 0,05 karena lebih kecil dari 0,05. Sehingga dapat disimpulkan bahwa LDR berpengaruh secara positif dan signifikan terhadap PBV sebesar 33,45\%. Sehingga hipotesis 3 yang menyatakan bahwa LDR berpengaruh positif dan signifikan terhadap PBV diterima. Perhitungan tersebut menunjukan bahwa pengaruh 
signifikan variabel LDR terhadap variabel PBV secara parsial berpengaruh positif dan signifikan.

\section{Uji F}

Perhitungan hasil Uji F pada tabel 4.13 diatas diperoleh nilai F hitung sebesar 7,726 dan hasil signifikansi sebesar 0,000. Dimana nilai probabilitas signifikansi pada tingkat signifikansi 0,05 karena lebih kecil dari 0,05, mkaa model regresi dapat digunakan untuk memprediksi PBV atau dapat dikatakan variabel ROE, DER, dan LDR secara bersama-sama berpengaruh terhadap PBV. Dengan demikian hipotesis 4 yang menyatakan terdapat pengaruh secara simultan antara variabel ROE, DER, dan LDR terhadap PBV diterima.

\section{Pembahasan}

\section{Pembahasan Deskriptif}

Berdasarkan hasil olah data deskriptif di tabel 4.5 di atas menunjukan bahwa Return on Equity memiliki nilai terendah (minimum) -52,07\%, nilai tertinggi (maksimum) 21,88\%, dan memiliki nilai rata-rata (mean) sebesar 5,9837\%. Besarnya rata-rata Return on Equity bank konvensional sudah cukup baik nilai ideal yang ditetapkan Bank Indonesia. Standar Return on Equity yang baik yang telah ditetapkan Bank Indonesia adalah 12,50\%. Nilai rata-rata (mean) sebesar 5,9837\% dengan standar deviasi Return on Equity sebesar 11,64444\% atau bisa dikatakan sebaran Return on Equity terdistribusi secara normal.

Berdasarkan hasil olah data deskriptif di tabel 4.5 di atas menunjukan bahwa Debt to Equity Ratio memiliki nilai terendah (minimum) 3,44\%, nilai tertinggi (maksimum) 10,89\%, dan memiliki nilai rata-rata (mean) sebesar 6,6216\%. Nilai rata-rata (mean) 6,6216\% dengan standar deviasi Debt to Equity Ratio sebesar 2,01673\% atau bisa dikatakan sebaran Debt to Equity Ratio terdistribusi secara normal.

Berdasarkan hasil olah data deskriptif di tabel 4.5 di atas menunjukan bahwa Loan to Deposit Ratio memiliki nilai terendah (minimum) 51,75\%, nilai tertinggi (maksimum) $112,13 \%$, dan memiliki nilai rata-rata (mean) sebesar $84,4371 \%$. Besarnya rata-rata Loan to Deposit Ratio bank konvensional sudah di atas nilai ideal yang ditetapkan Bank Indonesia. Standar Loan to Deposit Ratio yang baik yang telah ditetapkan Bank Indonesia adalah 78\%92\%. Nilai rata-rata (mean) sebesar $84,4371 \%$ dengan standar deviasi Loan to Deposit Ratio sebesar $12.69475 \%$ atau bisa dikatakan sebaran Loan to Deposit Ratio terdistribusi secara normal. 
Berdasarkan hasil olah data deskriptif di tabel 4.5 di atas menunjukan bahwa price book value memiliki nilai terendah (minimum) 0,33\%, nilai tertinggi (maksimum) 3,85\%, dan memiliki nilai rata-rata (mean) sebesar $1,7029 \%$. Besarnya rata-rata price book value bank konvensional sudah di atas nilai ideal yang ditetapkan Bank Indonesia. Standar price book value yang baik yang telah ditetapkan Bank Indonesia adalah 1,5\% (Ahmad Buyung Nusantara: 2009). Nilai rata-rata (mean) sebesar 1,7029\% dengan standar deviasi price book value sebesar $0,85155 \%$ atau bisa dikatakan sebaran price book value terdistribusi secara normal.

\section{Pembahasan Verifikatif}

Pada tabel 4.12 dijelaskan bahwa hasil uji t menyatakan bahwa variabel ROE memiliki t hitung 2,056 dengan probabilitas signifikan 0.048. dimana nilai probabilitas signifikansi 0,048 ini signifikan pada tingkat signifikansi 0,05 karena lebih kecil dari 0,05. Sehingga dapat disimpulkan bahwa ROE berpengaruh secara positif dan signifikan terhadap PBV sebesar 20,25\%. Sehingga hipotesis 1 yang menyatakan bahwa ROE berpengaruh positif dan signifikan terhadap PBV diterima. Perhitungan tersebut menunjukan bahwa pengaruh signifikan variabel ROE terhadap variabel PBV secara parsial berpengaruh positif dan signifikan.

Pada tabel 4.12 dijelaskan bahwa hasil uji t menyatakan bahwa variabel DER memiliki t hitung -2,195 dengan probabilitas signifikan 0.035. dimana nilai probabilitas signifikansi 0,035 ini signifikan pada tingkat signifikansi 0,05 karena lebih kecil dari 0,05. Sehingga dapat disimpulkan bahwa DER berpengaruh secara positif dan signifikan terhadap PBV sebesar 10,08\%. Sehingga hipotesis 2 yang menyatakan bahwa DER berpengaruh positif dan signifikan terhadap PBV diterima. Perhitungan tersebut menunjukan bahwa pengaruh signifikan variabel DER terhadap variabel PBV secara parsial berpengaruh positif dan signifikan. Setiap perusahaan membutuhkan dana untuk kegiatan operasional yang mencakup kinerja perusahaan (Sandy dan Asyik 2013). Hasil penelitian ini mendapatkan hasil bahwa debt to equity ratio (DER) atau struktur modal berpengaruh positif dan signifikan terhadap price book value (PBV).

Pada tabel 4.12 dijelaskan bahwa hasil uji t menyatakan bahwa variabel LDR memiliki t hitung 2,169 dengan probabilitas signifikan 0.037. dimana nilai probabilitas signifikansi 0,037 ini signifikan pada tingkat signifikansi 0,05 karena lebih kecil dari 0,05. Sehingga dapat disimpulkan bahwa LDR berpengaruh secara positif dan signifikan terhadap PBV sebesar 33,45\%. Sehingga hipotesis 3 yang menyatakan bahwa LDR berpengaruh positif dan signifikan terhadap PBV diterima. Perhitungan tersebut menunjukan bahwa pengaruh 
signifikan variabel LDR terhadap variabel PBV secara parsial berpengaruh positif dan signifikan.

Dilihat dari pihak emiten (manajemen perushaan) LDR merupakan faktor yang cukup penting dalam kegiatan usaha suatu perusahaan perbankan. Sehingga pihak manajemen harus bisa menjaga rasio LDR pada tingkat yang aman sesuai dengan yang ditetapkan bank indonesia, yaitu 78\% - 92\%, penarikan dana perbankan menjadi sangat meninggkat pada waktu bankbank menghadapi keketatan likuiditas (Laksana, 2010). Apabila bank dalam menyalurkan kredit dari dana pihak ketiganya tinggi maka otomatis likuiditas nya tinggi dan pendapatan bunganya akan tinggi.

Hasil pengujian pengaruh simultan variabel Return on Equity (ROE), Debt to Equity Ratio (DER), dan Loan to Deposit (LDR) terhadap Nilai Perusahaan (PBV) pada Bank Konvensional yang Terdaftar di Bursa Efek Indonesia antara lain:

a. Variabel Return on Equity (ROE), Debt to Equity Ratio (DER), dan Loan to Deposit (LDR) terhadap Nilai Perusahaan (PBV) pada Bank Konvensional yang Terdaftar di Bursa Efek Indonesia menyatakan bahwa variabel Return on Equity (ROE), Debt to Equity Ratio (DER), dan Loan to Deposit (LDR) secara bersama-sama berpengaruh signifikan terhadap variabel Nilai Perusahaan (PBV).

b. Koefisien determinasi $\left(\mathrm{R}^{2}\right)$ menyatakan bahwa variabel Return on Equity (ROE), Debt to Equity Ratio (DER), dan Loan to Deposit (LDR) memberikan konstribusi terhadap variabel Nilai Perusahaan (PBV) sebesar 63,7\% sedangkan sisanya 36,3\% dipengaruhi oleh faktor-faktor yang tidak diteliti.

Koefisien korelasi menunjukan bahwa hubungan antara variabel Return on Equity (ROE), Debt to Equity Ratio (DER), dan Loan to Deposit (LDR) terhadap nilai perusahaan (PBV) adalah sebesar $63,7 \%$ artinya hubungannya kuat dan signifikan.

\section{KESIMPULAN DAN IMPLIKASI}

\section{Kesimpulan}

Berdasarkan hasil penelitian ini dapat dikemukakan beberapa kesimpulan sebagai berikut:

1. Kondisi ROE, DER, dan LDR pada Bank umum yang Terdaftar di Bursa Efek Indonesia masih dalam kategori wajar dan tidak melanggar batas ketentuan dari Bank Indonesia atau Otoritas Jasa Keuangan. Dalam industri perbankan, melanggar aturan dan ketentuan yang telah ditetapkan oleh Bank Indonesia atau Otoritas Jasa Keuangan akan mendapatkan sanksi sehingga semua perbankan akan berupaya untuk memenuhi 
aturan dan ketentuan yang sudah ditetapkan oleh Bank Indonesia atau Otoritas Jasa Keuangan.

2. PBV pada Bank Konvensional yang Terdaftar di Bursa Efek Indonesia memiliki ratarata $1,7 \%$ dan angka ini sudah diatas nilai ideal dari Bank Indonesia yaitu 1,5\%.

3. Pengaruh secara parsial ROE, DER, dan LDR terhadap PBV pada Bank umum yang Terdaftar di Bursa Efek Indonesia yaitu:

a. ROE berpengaruh positif terhadap PBV sebesar 20,25\% pada Bank umum yang Terdaftar di Bursa Efek Indonesia periode tahun 2015-2019.

b. DER berpengaruh positif terhadap PBV sebesar 10,08\% pada Bank umum yang Terdaftar di Bursa Efek Indonesia periode tahun 2015-2019.

c. LDR berpengaruh positif terhadap PBV sebesar 33,45\% pada Bank umum yang Terdaftar di Bursa Efek Indonesia periode tahun 2015-2019.

4. Terdapat pengaruh secara simultan ROE, DER, dan LDR terhadap PBV sebesar 63,78\% pada Bank umum yang Terdaftar di Bursa Efek Indonesia periode tahun 20152019.

\section{Implikasi}

Berdasarkan simpulan dan pembahasan pada bab-bab sebelumnya, maka dikemukakan beberapa saran yang diharapkan dapat berguna bagi pihak terkait sebagai berikut:

1. Bagi Perusahaan

Pada penelitian ini secara parsial Return on Equity (ROE), Debt to Equity Ratio (DER), dan Loan to Deposit (LDR) mempunyai pengaruh positif terhadap Nilai Perusahaan (PBV). Hal ini menunjukan bahwa perusahaan perlu memperhatikan faktor tersebut sehingga dapat menarik pihak investor untuk menanamkan modalnya sehingga permintaan saham akan tinggi, harga saham dan nilai perusahaan pun meningkat.

2. Bagi Investor dan Calon Investor

Bagi investor diharapkan untuk melakukan pertimbangan dalam melakukan investasi dengan menganalisis terlebih dahulu kondisi perusahaan melalui Return on Equity (ROE), Debt to Equity Ratio (DER), dan Loan to Deposit (LDR), karena dalam penelitian ini rasio tersebut mempunyai pengaruh positif terhadap nilai perusahaan. Dengan memperhatikan faktor-faktor yang mempengaruhi nilai perusahaan diharapkan investor dapat menyusun portofolio investasi secara optimal memaksimalkan return dengan tingkat resiko tertentu

3. Bagi Peneliti Selanjutnya 
Penelitian ini memiliki keterbatasan penelitian yaitu periode penelitian yang tidak ada jeda tahun antara rasio pada variabel $\mathrm{X}$ dengan $\mathrm{PBV}$ pada variabel $\mathrm{Y}$. Seharusnya pada variabel Y perhitungannya menggunakan closing price setelah tanggal publikasi sehingga terdapat jeda tahun antara rasio pada variabel $\mathrm{x}$ dan PBV pada variabel Y.

Penulis juga menyarankan kepada peneliti selanjutnya untuk menambahkan variabel lain yang diduga mempunyai pengaruh terhadap nilai perusahaan, seperti DPR, NPM, ROA, dan SIZE. Selain itu juga diharapkan untuk menambah periode tahun penelitian dan juga menggunakan unit analisis yang berbeda dengan penelitian ini, seperti pada perusahaan manufaktur atau pada sektor industri barang dan konsumsi lainnya..

\section{DAFTAR PUSTAKA}

Apriada K, Suardikha M S. 2016. Pengaruh Struktur Kepemilikan Saham, Struktur Modal Dan Profitabilitas Pada Nilai Perusahaan. E-Jurnal Ekonomi dan Bisnis Universitas Udayana 5.2: 201-218.

Arikunto S. 2006. Prosedur Penelitian : Suatu Pendekatan Praktek.jakarta (ID): Bina Aksara. Burja, Camelia. 2011. Factor Influencing The Companies Profitability. Jurnal Faculty of Science: $23-41$.

Brigham EF, Houston JF. 2006. Dasar-Dasar Manajemen Keuangan. Alih Bahasa Ali Akbar Yulianto.ed ke-10 Jakarta: Salemba empat.

Dawood, Usman. 2014. Factors Impacting Profitability of Commercial Banks In Pakistan for The Period of 2009-2012. International Journal of Scientific and Research Publication Volume 4, Issues 3.

Dira P Kadek, Astika I B Putra. 2014. Pengaruh Struktur Modal, Likuiditas, Pertumbuhan Laba, dan Ukuran Perusahaan pada Kualitas Laba. E-Jurnal Ekonomi dan Bisnis Universitas Udayana 7.1: 64-78.

Dendawijaya, Lukman. 2005. Manajemen Perbankan. Bogor: Ghalia Indonesia.

Dewi M A Sri, Wirajaya A. Pengaruh Struktur Modal, Profitabilitas dan Ukuran Perusahaan. E-Jurnal Ekonomi dan Bisnis Universitas Udayana 4.2: 358-372.

Fahmi, Irfan. 2011. Analisis Laporan Keuangan. Bandung: Alfabeta

Fakhruddin, Hadianto S.2004. Perangkat dan Model Analisis Investasi di pasar Modal. Ed ke1. Jakarta (ID): Elex Computindo. 
Gideon, Frednard et al. 2016. Bank Liquidity and The Global Financial Crisis. Journal of Applied Mathemathics: 1-27.

Ghozali I. 2006. Aplikasi Analisis Multivariate dengan Program SPSS, Semarang (ID): BP Universitas Diponegoro.

Hampton, John J. 2006, Financial Decision Making, Concepts, Problems nd Chase, Ed ke-4. India (IND): Prentice hall.

Hariani MDPP. 2012. Faktor-faktor yang mempengaruhi nilai perusahaan (studi Pada perusahaan yang terdaftar di Jakarta Islamic Index 2007-2010). Jakarta (ID); Universitas Sumatra Utara.

Hartono, 2013. Teori Portofolio dan Analisis dan Investasi. Yogyakarta (ID): BPFE.

Hasan, M Iqbal. 2002. Pokok-pokok Materi Metodologi Penelitian dan Aplikasinya. Jakarta: Ghalia Indonesia.

Hasan M Fadhil, Listiyanto E. Analysis of Factors Affecting Banking Intermediation in Indonesia. MAC Praque Consulting: 368-374.

Haryanto, Sugeng. 2016. Profitability Identification Of National Banking Through Credit, Capital, Capital Structure, Efficiency, And Risk. Jurnal Dinamika Manajemen: 11-21.

Hermuningsih, Sri. 2013. Pengaruh Profitabilitas, Growth Opportunity, Struktur Modal Terhadap Nilai Perusahaan Pada perusahaan Publik Di Indonesia. Jurnal Buletin Ekonomi Moneter Dan Perbankan: 128-147.

Hidayat M. (2014). Pengaruh rasio kesehatan perbankan terhadap nilai Perusahaan (studi kasus pada perbankan yang terdaftar di BEI). Jurnal Ekonomi dan Informasi Akutansi. 4(1): 41-47.

Horne V, James C, Machowicz JM JR. 2005. Fundamental of Financial Management Prinsipprinsip Manajemen Keuangan. Ed ke-12.Jakarta(ID): Salemba Empat.

Husnan S.pudjiastuti E. 2004. Dasar-dasar manajemen keuangan .yogyakarta (ID):UPP AMP YKPN.

Javaid, Saira et al. 2011. Determinants of Bank Profitability in Pakistan: Internal Factor Analysis. Journal of Yasar University: 3794-3804.

Kasmir. 2011. Bank lembaga keuangan lainnya ED rev 2008. Jakarta (ID): Raja grafindo press.

Kusuma, Indra et al. 2014. Pengaruh resiko keuangan terhadap nilai perusahaan perbankan yang terdaftar di bursa efek Indonesia. Jurnal manajemen bisnis indonesia 3(4):1-11. Lubis, Ignatius L. 2016. The Effect of Profitability, Capital Structure, and Liquidity on Company Value. Jurnal Ekonomi dan Bisnis: 34-37. 
Lukman S . 2000. Manajemen Keuangan Jakarta (ID): Raja grafindo persada.

Mishkin, Frederic S. 2017. Ekonomi, Uang, Perbankan, dan Pasar Keuangan. Jakarta Selatan: Salemba Empat.

Nazir, Mohamad. 2011. Metode Penelitian. Jakarta: Ghalia Indonesia

Parvez A, Nanda S. 2000. Style Inveting incorporating growth characteristics in Value stoks. Pennsylvania State University at Harrisburg. 2(1): 1-27.

Parvin A, Nitu A Akter. 2016. Factors Affecting the Liquidity Level of Commercial Banks in Bangladesh. ASA University Review Volume 10: 2.

Priyatno, Duwi. 2010. Paham Analisa Statistik Data Dengan SPSS. Yogyakarta: MediaNom.

Putra DK. 2016. Pengaruh Risio Likuiditas pada Kinerja Perbankan Umum Syariah dan Perbankan Umum Konvesia di Indonesia Yogyakarta (ID): Univesitas Gadjah Mada.

Putu, Martini NG, Moeljadi, Djumahir, Djazuli A, 2014. Factors Affenting Firms Value $f$ Indonesia Public Manufacturing Firms. International Journal of Business and Management Invention 2(2):35-44.

Putu Y, Gede A, Ananta W. 2014. Pengaruh Struktur Modal, Pertumbuhan Perusahaan, dan Profitabilitas Terhadap Nilai Perusahaan LQ45 Di Bursa Efek Indonesia Periode 20082012. Jurnal Akutansi S1 Volume 2: 1.

Repi S, Murni S, Adare D. 2016. Faktor-faktor yang mempengaruhi nilai Perusahaan subsektor perbankan pada BEI dalam menghadapi MEA.

Riyanto B 2008. Dasar-dasar Pembelanjaan Perusahaan. Ed ke-4. Yogyakarta (ID): BPFE.

Rompas, Gisella P. 2013. Likuiditas, Solvabilitas, dan Rentabilitas Terhadap Nilai Perusahaan BUMN Yang Terdaftar Di Bursa Efek Indonesia. Jurnal EMBA: 252-262.

Sari AAPA, Ardiana PA. 2014. Pengaruh Board size terhadap nlilai perusahaan EJurnal Akuntansi Universitas Udayana. 7(1): 177-191

Udayana. 14(2): 1183-1209.

Saidi 2004. Faktof-faktor yang mempengaruhi struktur modal pada perusahaan Manufaktur go public di BEJ Tahun 1997-2002. Jurnal Bisnis dan Ekonomi 11(1): 58-76.

Sitanggang, J P. 2014. Manajemen Keuangan Perusahaan ED.2. Jakarta: Mitra Wacana Medika.

Sjahrial, Dermawan. 2012. Pengantar Manajemen Keuangan. Jakarta: Mitra Wacana Medika. 
Sofyan, Harahap S 2007. Analisis Kritis atas Laporan Keuangan. Jakarta (ID) Ranja Grafindo Persada.

Soliha E, Taswan 2002. Pengaruh kebijakan hutang terhadap nilai perusahaan Serta beberapa faktor yang mempengaruhinya. Jurnal Bisnis dan Ekonomi 9(2): 149-163.

Sudaryono. 2014. Pengantar Manajemen: Teori Dan Kasus. Jakarta: Buku Seru.

Sufian, Fadzlan. 2012. Determinants of Bank Profitability in Developing Economics: Empirical Evidence from The South Asian Banking Sectors. Routledge Taylor and Francis Group Volume 20: 3.

Sugiyono .2013. Memahami Penelitian Kualitatif Bandung(ID): Alfabeta.

Sujoko, Soebintoro U. 2007. Pengaruh struktur kepemilikan, leverage, faktor Intern, dan faktor ekstren terhadap nilai perusahaan (studi empirik pada Perusahaan manufaktur dan non manufaktur di bursa Efek Jakarta). Jurnal Manajemen dan Kewirausahaan. 9(1): 41-49

Suharli, Michelli. 2006. Studi Empiris Terhadap Faktor Yang Mempengaruhi Nilai Perusahaan Pada Perusahaan Go Public Di Indonesia. Jurnal MAKSI: 23-41.

Sukimi D 2012. Kepemilikan manajerial, kepemilikan institusional, kebijakan Deviden dan kebijakan hutang analisis terhadap nilai perusahaan. Accounting Analysis Journal 1(2): 1-12.

Susilowati Y, Turyanto T 2011. Reaksi signal rasio profitablitas dan rasio Solvabilitas terhadap return saham perusahaan. Dinamika Keuangan Dan Perbankan 3(1): 17-37.

Supriyadi, Didit. 2017. Integrasi, Pendidikan, dan Kinerja: Studi Empirik pada Perbankan. Bandung: Manggu Makmur Tanjung Lestari.

Tampubolon, Manahan P. 2013. Manajemen Keuangan (Finance Management). Jakarta: Mitra Wacana Medika.

Teguh P, Mulyono. 2001. Manajemen Perkreditan Komersil. Yogyakarta: BPFE. Triandaru S, Budisantoso T. 2004. Bank dan Lembaga Keuangan Lain. Jakarta (ID): Salemba Empat.

Ulupui IGKA, 2005. Analisis pengaruh rasio likuiditas, leverage, aktivitas dan Profitabilitas terhadap return saham: studi pada perusahaan makanan Dan minuman dengan 
kategori industri barang konsumsi yang tedaftar Di bursa efek jakarta. Audi Jurnal Akutansi dan Bisnis. 2(1): 1907-3771.

Uniariny, 2012. Pengaruh struktur modal dan modal intelektual terhadap nilai Perusahaan sektor perbankan yang terdaftar di BEI periode 2006-2010. Jakarta (ID): Universitas Indonesia.

Utama AT, Rohman A, 2013. Pengaruh corporate governance perception index, Profitabilitas, leverage, dan ukuran perusahaan terhadap nilai saham, Diponegoro Journal of Accounting. 3(1): 1-9.

Uma S, Roger B. 2017. Metode Penelitian Untuk Bisnis. Jakarta: Salemba Empat.

Wahidahwati. 2002. Kepemilikan Manajerial dan agency conflict: analisis

Persamaan simultan non linier dari kepemilikan manajerial, penerimaan

Risiko(risk taking), kebijakan hutang dan kebijakan deviden, Simposiun

Nasional Akutansi.

Wahyudi U, Pawestri PH, 2006. Implikasi struktur kepemilikan, terhadap nilai

Perusahaan dengan keputusan keuangan sebagai variabel intervening

Simposium Nasional Akutansi 9 Padang(ID): KAKPM 17.

Wardhani SI, 2012. Pengaruh penerapan manajemen risiko terhadap return Harga saham industri perbankan di Indonesia. Jakarta(ID): Universitas Indonesia..

Wijaya LRP, Wibawa BA 2010. Pengaruh Keputusan Investasi. Keputusan Pendanaan dan Kebijakan Dividen terhadap Nilai Perusahaan. Purwokerto(ID): SNA XIII.

Wulandari, Retno. 2013. Pengaruh Profitabilitas, Operating Leverage, Likuiditas Terhadap Nilai Perusahaan Dengan Struktur Modal Sebagai Intervening. Jurnal Accounting Analysis: 455-463.

Yudiartini DAS, Dhramadiaksa IB. 2016. Pengaruh rasiio keuangan terhadap Kinerja jeuangan sector perbankan di BEI. E-jurnal akutansi Univesitas. 